\title{
NON-EPITHELIAL TUMORS OF THE NOSE, NASOPHARYNX AND PARANASAL SINUSES - A CLINICOPATHOLOGICAL STUDY
}

\author{
ALAM ABMK ${ }^{1}$, TALUKDER DC ${ }^{2}$, AICH ML $^{3}$, HARUN MAA ${ }^{4}$, RUMI SNF $^{5}$, ISLAM MN ${ }^{6}$
}

\begin{abstract}
:
Total 392 sino-nasal tract tumours were examined histopathologically of which 79 cases came out as non ephithelial tumors during a study period of three years from 2009 to2011. Epistaxis and nasal obstruction were the two most common presenting symptoms. Facial swelling, sinus tenderness \&nasal airway obstruction were the commonest sign. Capillary haemangioma \& nasopharyngeal angiofibroma were the commonest benign tumor where as lymphoma and rhabdomyosarcoma were the two most common malignant lesions.
\end{abstract}

J Dhaka Med Coll. 2012; 21(1) : 41-45.

\section{Introduction:}

Tumors of the nose, nasopharynx $\&$ para nasal sinuses are incidence wise not very common, but a wide variety of both benign and malignant tumors occur there ${ }^{1}$. As early as $5^{\text {th }}$ century B. C., great physician Hippocrates first described tumors of this region ${ }^{2}$. Series on tumors of sinonasal tract were published by Ringertz in $1938^{3}$ and Eggston in $1947^{4}$.

Classification of these neoplasm is based upon the international histological classification of tumors by World Health Organization ${ }^{5}$.Broadly the neoplasms are categorized into epithelial, non epithelial and tumors like conditions ${ }^{6}$. We in our study, only included non-epithelial tumors of the sinonasal tract. . All other tumors like conditions, epithelial neoplasms and inflammatory lesions mimicking neoplasm, were excluded from the study.

\section{Aims \& Objectives:}

The study was done in order to:

(a) Find out the incidence of non-epithelial tumors (NETs) among all sino-nasal swellings, biopsied.

(b) Know the age sex distribution, common clinical presentations and usual signs of these neoplasms. (c) Study the histopathogical classification of non-epithelial tumours of sino-nasal tract with incidence of individual tumors.

\section{Materials and Methods:}

Present study was done in the Dept. of ENT, Dhaka Medical College hospital for a period of 3 years from 2009 to 2011 .

During this period, the entire patient had surgery for sino-nasal tract tumours\& tumours specimen routinely sent for histopathology with request for special stain like reticulin were used as \& when necessary. Where the histopathological diagnosis was that of a nonepithelial tumour then detailed history, clinical findings, investigation reports $\&$ other relevant information were collected for study purpose.

Finally, all these collected datas are analysed by simple statistical.method.

\section{Results:}

During the period of study, 392 sinonasal tract tumours were biopsied and histopathological reports were received. The results of hitopathological study are described in Table 1.

1. Dr. A.B.M. Khorshed Alam, Assistant Professor-ENT, Dhaka Medical College, Dhaka

2. Dr. Debesh Chandra Talukder, FCPS, Assistant Professor-ENT, Dhaka Medical College

3. Dr. Mani Lal Aich, MS, Assistant Professor-ENT, Sir Salimullah Medical College, Dhaka

4. Dr. Md. Abdullah Al Harun, FCPS, Deputed to BSMMU, OSD, DG (Health), Dhaka.

5. Dr. SK. Nurul Fattah Rumi, MS, Assistant professor-ENT, Dhaka Medical College, Dhaka

6. Dr. Md. Nazmul Islam, MS,MPH, Assistant professor of ENT, Dhaka Medical College, Dhaka

Correspondence : Dr. A.B.M. Khorshed Alam, FCPS, Assistant Professor-ENT, Department of ENT, Dhaka Medical College, Dhaka 
Male cases were outnumbered by females in all categories of lesions. Overall, male female ratio was 2.01:1. But in case of non-epithelial tumours, the ratio was approximately 2.59:1.

Table 2 describes the location wise incidence of the non-epithelial tumors of sinonasal tract. In all three sites, male cases were commoner than females and nose was the commonest location, involved. Age-Sex distribution of these tumors are expressed in Table 3. Maximum number of cases were reported in the $3^{\text {rd }}$ decade 39 (49.37\%) followed by $11-20$ year $\left(2^{\text {nd }}\right.$ decade) age group 15 (18.98\%). Youngest case was a 3 year old female child with haemangioma where as oldest reported case was male aged 67 years with chondrosarcoma.

Table-I

Incidence oflesions( $n=392)$

\begin{tabular}{llccc}
\hline No of cases & No of epithelial & $\begin{array}{c}\text { No of non- } \\
\text { lesions }\end{array}$ & epithelial lesions & $\begin{array}{c}\text { No of inflammatory } \\
\text { lesions }\end{array}$ \\
\hline Male & 262 & 102 & 57 & 103 \\
Female & 130 & 51 & 22 & 57 \\
Total & $392(100 \%)$ & $153(39.03 \%)$ & $79(20.15 \%)$ & $160(40.80 \%)$ \\
\hline
\end{tabular}

Table-II

Site of lesions, non-epithelial tumour( $n=79$ )

\begin{tabular}{lccccc}
\hline No of cases & Nose & Nasopharynx & Paranasal sinuses & Male & Female \\
\hline $79(100 \%)$ & $46(58.22 \%)$ & $09(11.39 \%)$ & $24(30.38 \%)$ & 54 & 25 \\
\hline
\end{tabular}

Table-III

Age-Sex distribution ( $n=79$ )

\begin{tabular}{lcccccccc}
\hline Sex & $\begin{array}{c}\text { No of } \\
\text { cases }\end{array}$ & $\begin{array}{c}0-10 \\
\text { years }\end{array}$ & $\begin{array}{c}11-20 \\
\text { years }\end{array}$ & $\begin{array}{c}21-30 \\
\text { years }\end{array}$ & $\begin{array}{c}31-40 \\
\text { years }\end{array}$ & $\begin{array}{c}41-50 \\
\text { years }\end{array}$ & $\begin{array}{c}51-60 \\
\text { years }\end{array}$ & $\begin{array}{c}60-70 \\
\text { years }\end{array}$ \\
\hline Male & 54 & 02 & 11 & 26 & 07 & 04 & 02 & 02 \\
Female & 25 & 01 & 04 & 13 & 04 & 02 & 01 & 00 \\
\hline
\end{tabular}

Table-IV

Clinical presentation ( $n=79$ )

\begin{tabular}{lcccccc}
\hline Site of lesions & $\begin{array}{c}\text { No of } \\
\text { cases }\end{array}$ & Epistaxis & $\begin{array}{c}\text { Nasal } \\
\text { obstruction }\end{array}$ & $\begin{array}{c}\text { Nasal } \\
\text { Voice }\end{array}$ & Dysphagia & Headache \\
\hline Nose & 46 & 44 & 41 & 04 & 00 & 08 \\
PNS & 24 & 22 & 07 & 04 & 01 & 11 \\
Nasopharynx & 09 & 07 & 06 & 04 & 02 & 05 \\
\hline Total & $79(100 \%)$ & $73(92.40 \%)$ & $54(68.35 \%)$ & $12(15.18 \%)$ & $03(3.79 \%)$ & $24(30.38 \%)$ \\
\hline
\end{tabular}

Table V

Signs of tumours including radiological findings $(n=79)$

\begin{tabular}{lcccccc}
\hline Site of lesions & $\begin{array}{c}\text { No of } \\
\text { cases }\end{array}$ & $\begin{array}{c}\text { Facial } \\
\text { swelling }\end{array}$ & $\begin{array}{c}\text { Sinus } \\
\text { tenderness }\end{array}$ & $\begin{array}{c}\text { Nasal airway } \\
\text { obstruction }\end{array}$ & $\begin{array}{c}\text { Lymphaden- } \\
\text { opathy }\end{array}$ & $\begin{array}{c}\text { Radiology, } \\
\text { haziness of } \\
\text { sinuses }\end{array}$ \\
\hline Nose & 46 & 18 & 41 & 46 & 00 & 46 \\
PNS & 24 & 12 & 07 & 24 & 01 & 24 \\
Nasopharynx & 09 & 03 & 06 & 07 & 02 & 05 \\
\hline Total & $79(100 \%)$ & $33(4177 \%)$ & $54(68.35 \%)$ & $77(97.46 \%)$ & $03(3.79 \%)$ & $75(94.93 \%)$ \\
\hline
\end{tabular}




\section{Table -VI}

Distribution of neoplastic lesions. $(n=79)$

\begin{tabular}{lccccccccc}
\hline Site of lesions & No of & & \multicolumn{3}{c}{ Benign } & & \multicolumn{3}{c}{ Malignant } \\
& case & & Male & Female & Total & & Male & Female & Total \\
\hline Nose & 46 & 29 & 10 & 39 & & 05 & 02 & 07 \\
Nasopharynx & 09 & 04 & 02 & 06 & & 02 & 01 & 03 \\
PNS & 24 & 09 & 06 & 15 & & 07 & 02 & 09 \\
Total & 79 & 32 & 18 & 60 & & 14 & 05 & 19 \\
\hline
\end{tabular}

Table-VII

Histopathological diagnosis of non-epithelial tumour $(n=79)$

\begin{tabular}{llclc}
\hline Tissue of origin & Benign & No of cases & Malignant & No of cases \\
\hline Vascular: & Capillary haemangioma & 20 & Haemangiopericytoma & 01 \\
& Nasopharyngeal Angiofibroma & 17 & & \\
Fibro-osseous: & osteoma & 05 & & \\
& Ossifying fibroma & 07 & & 06 \\
Reticuloendithelial: & & & Lymphoma & 02 \\
& & & Plasmacytoma & \\
Neurogenic: & Neurofibroma & 03 & & 01 \\
& Schwannoma & 05 & & 05 \\
Fibrous & Fibroma & 03 & Fibrosarcoma & 03 \\
Myogenic & & & Rhabdomyosarcoma & 01 \\
Olfactory & & & Olfactory neuroblastoma & Chondrosarcoma \\
Chondrogenic & & & &
\end{tabular}

Table-VIII

Site distribution of malignant lesions $(n=19)$

\begin{tabular}{lcccc}
\hline Malignant tumour & Nose & Nasopharynx & PNS & Total \\
\hline Haemangiopericytoma & 01 & 00 & 00 & 01 \\
Lymphoma & 02 & 01 & 03 & 06 \\
Plasmacytoma & & 01 & 01 & 02 \\
Fibrosarcoma & 01 & 00 & 00 & 01 \\
Chondrosarcoma & 00 & 00 & 01 & 01 \\
Rhabdomyosarcoma & 01 & 01 & 03 & 05 \\
Olfactory neuroblastoma & 02 & 00 & 01 & 03 \\
Total & $07(36.84 \%)$ & $03(15.79 \%)$ & $09(47.36 . \%)$ & $19(100 \%)$ \\
\hline
\end{tabular}

Common clinical presentations of these tumors are tabulated in Table 4. Epistaxis was the commonest presenting symptom for nasal lesions. Nasal obstruction was the second most common symptom and along with nasal voice change it qualified for most common symptom for nasopharyngeal lesions.
Nasal obstruction was also the commonest presentation for para nasal sinus lesions.

Signs of the tumors are expressed in Table 5. Nasal air way obstruction \&facial swelling were the commonest sign of all tumors, as also for nasopharyngeal and paranasal sinus growths. Sinus tenderness was the commonly elicited 
sign 54(68.35\%) of which 41 (51.90\%) in nasal neoplasms. 75 out of 79 cases (94.93\%) showed haziness of sinuses on radiology. But in case of PNS \&nasal lesions , sinus haziness is $100 \%$.

Table 6 : Described the site wise incidence of benign and malignant lesions. Benign tumors far outnumbered malignant tumors in the ratio of 3.16:1. Maximum number of malignant cases occurred in Para nasal sinuses on the other hand, maximum number of benign tumors occurred in the nose. Male cases were commoner than females in all category of tumors.

Histopathological diagnosis of individual tumors are discussed in Table 7. Vascular tumors were the commonest lesions (37 out of 79 i.e. $46.84 \%)$ and capillary haemangioma $20(25.31 \%)$ followed by angiofibroma $17(21.51 \%)$ were the most common tumors. In the malignant group, reticuloendothelial tumors $(8$ out of 79 i.c. $10.12 \%$ ) and myogenic tumorsrhabdomyosarcoma $05(6.33 \%)$ were the two most common malignant tumor. In the concluding Table 8 the datas related to distribution of malignant tumors are tabulated.

\section{Discussion:}

As there were only few reported series on nonepithelial tumors of Sino-nasal tract ${ }^{617,8,9}$, we compared our datas with the few published datas available.

Regarding age distribution, Fu \& Perzin ${ }^{6,7,8}$ got most of the tumors in $4^{\text {th }} \& 5^{\text {th }}$ decade. Comparatively, lower age group of cases in our series (Maximum pervalance in $3^{\text {rd }}$, followed by $2^{\text {nd }}$ decade), could be due to larger population of vascular tumors ( 37 out of 79 in our group vs 85 out of 256 in the group of Fu \& Perzin) $)^{6}$.

Male cases outnumbered females in all study groups supporting our findings.

Regarding symptoms, epistaxis followed by nasal obstruction were most common in our series. In a large series of non-epithelial malignant tumors of this region nasal obstruction followed by epistaxis were the commonest presenting features ${ }^{4}$.

Benign tumors were much more common than malignant lesions series, as also the experience of Fu \& perzin $^{6,7,8}$ and Eggston and Wolff ${ }^{4}$.

Vascular tumors were the commonest sinonasal non epithelial neoplasm both in our study, as well as in previous studies ${ }^{9,10}$, Though juvenile angiofibroma was reported to be the commonest vascular tumor in different publication $^{8,9}$ in our experience this tumor came second only to capillary haemangioma regarding incidence.

It is reported that lymphoma account for $1 \%$ of all head and neck malignancies. Reticuloendothelial tumors followed by rhabdomyosarcoma were reported previously as most common malignant lesions ${ }^{6.7}$. Sino-nasal tract lymphomas are common malignancy followed by rhabdomyosarcoma in our series.

There were total 8 cases of neurogenic tumors in our series and majority of them, occurred in the nose \& maxillary sinus. Among fibroosseous lesions, osteoma and ossifying fibroma were quite common.

Olfactoryneuroblastoma was the commonest malignant tumor involving nose and paranasal sinuses. Lymphoma and rhabdomyosarcoma were most common malignant tumour, involving nose, paranasal sinuses \&nasopharynx.

Other relatively uncommon tumors reported in our study group included fibroma, plasmacytoma, chondrosarcoma, , fibrosarcorna, malignant haemangiopericytoma. These variants were also reported by other workers $6,9,12,13,14,15$.

A lot of other rare tumors namely glomangioma, oncocytoma, chordoma, malignant paraganglioma, teratocarcinoma etc. were reported by different authors ${ }^{16,17,18,19,20}$, though not found by us.

Lipoma, so much a common tumor in different parts of the body, was seldom reported from this region ${ }^{21}$ and we also did not get a single case.

\section{Conclusion:}

In this study, we wanted to throw light on relatively less searched areas of pathology. As there was scarcity of printed materials in this particular field .Our progress was not very smooth. But in conclusion, we are able to express, datas related to the age-sex 
distribution, clinical presentation, incidence and histopathological types of non-epithelial benign and malignant tumors of nose, nasopharynx and para nasal sinuses. We hope that it would pare the pathology of further detailed studies of these tumors.

\section{References:}

1. Hormann K: Tumors of the nasal cavity and the paranasal sinuses an update of current opinions and advances in etiology, diagnosis \& therapy: Otolayngol pol: 2000; 54(3): 251-8.

2. R. Scott Stevenensen:A history of otolaryrgology : page : 194-99: E \& S Livingstone Ltd.

3. Ringertz N(1938) : Pathology of malignant tumors arising in nasal \& paranasal cavities \& Maxilla : Acta otolaryngologica (Suppl) : 27-1-405.

4. Eggaton \& Wolf (1947) : Histopathology of the Ear, Nose and Throat : Williams and Wilkins Publications: Baltimore : p. 761.

5. Shanmugaratnam K, Soibn LH 1978: Histological typing of upper respiratory tract tuact tumors. World Health Oraganization. Geneva. P. 15-18.

6. Fu \& Perzin (1976) : Non-epithelial tumors of the nasal cavity. PNS \& nasopharynx - a clinicopathologic study v : Skeletal muscle tumor (Rhabdomyosarcoma and Rhabdomyoma) : Cancer 37: 364-76.

7. Fu YS and perzin KH (1974) : Non- epithelial tumors of nasal cavity, paranasal sinuses and nasopharynx- a clinicopathologic study III, cartilaginous tumor-chandrosarcoma, chondroma. Cancer 34:453-63.

8. Fu YS and perzin KH (1976) : Non- epithelial tumors of nose, paranasal sinuses and nasppharynx VI. Fibrous tissue tumors : cancer 37: 2912.

9. Yao SF and Karl HP (1974) : Non- epithelial tumors of nasal cavity, paranasal sinuses and nasophaynx-A clinicopathologic study : cancer 33:1289-1305.
10. Jhonson $\mathrm{MH}$ : Vascular lesion of the paranasal sinuses and nasal cavity : Semim. Ultrasound CTMR 1999 ; Dec. 20(6): 426-44.

11. V. P. Keyzer S, P. Eloy, M Delos et al. : Sinonasal lymphoma-case report : Acta Otorhinolaryngol Belg 2000 ; 54(1) : 45-51.

12. LD Thomsen, LA GYURE : Extra cranial sinonasal tract menigiomas : A clinicopathologic study of 30 ases with a review of the literature : Am J Surg Pathol 2000 May : 24(5) : 640-50.

13. SR Gadwal, JC Fanburg - Smith, FG Gannen, LD. Thompson : Primary chondrosarcoma of the head $\&$ neck in paediatric patients : a clinicopathologic study of 14 cases with a reviw of the literature : Cancer 2000 May 1:88(9):2181-8.

14. Marianowski, M Wassef, P Horman, PT Huy : Nasal haemangiopericytoma report of two cases with literature review J. laryngol. Otol 1999 may ; 113(3) :199-206.

15. V. Cumbo, G. Gullina : P. Merrina Extramedullary plasm acytom as of the maxillary sinus : report of a case. Journal of otolaryngology \& neck surgery (1988) : $46: 406-09$.

16. J constantinidis, A. Kiefer, K Reitnaver, H Iro : Glomangioma of the nasal cavity and paranasal sinuses : Rhinology 2000Sep ; 38(3) : 136-9.

17. J Cerbridge, AP Gallimose,CG Dalton, PE O'Flynn : Oncocytoma of the upper jaw, Head Neck 1996 Jul- Aug. 18(4) : 374-80.

18. S, Loughran, L Badia, V Lund: Primary Chordoma of the ethmoid sinuses, J. Laryngol Otol : 2000 Aug; 114(8) : 627-29.

19. HS Sharma, M. Madhavan, NH Othman, M. Muhamad, J.M.Abdullah : Malignant paraganglioma of frontocthmoidal region : Arus Nasus Larynx 1999 oct; 26(4) : 487-93

20. Hs Sharma, J. M.Abdullah, NH Othman, M. Muhamad: Tertocarcinosarcoma of the nasal cavity and ethmoid, J Larynagol otol 1998 Jul, 112(7) : 682-26.

21. K. Takasaki, H. Kano, T. Hayashl, T. Kobayashi: Nasal Lipoma : J. Laryngol otol 2000; 114(3), 21820. 